
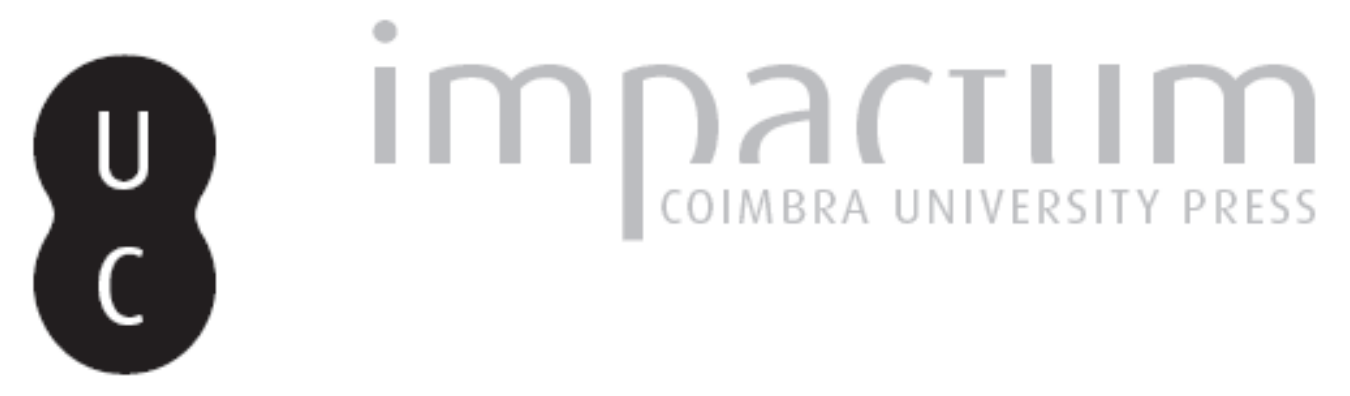

\title{
Examining the design, style and layout of the inner coffin from A.60 in the Florence Egyptian Museum
}
Autor(es):
Sousa, Rogério
Publicado por: Centro de História da Universidade de Lisboa
URL persistente:
URI:http://hdl.handle.net/10316.2/44035
DOI:
DOI:https://doi.org/10.14195/0871-9527_26_3

Accessed : $\quad$ 26-Apr-2023 12:03:38

A navegação consulta e descarregamento dos títulos inseridos nas Bibliotecas Digitais UC Digitalis, UC Pombalina e UC Impactum, pressupõem a aceitação plena e sem reservas dos Termos e Condições de Uso destas Bibliotecas Digitais, disponíveis em https://digitalis.uc.pt/pt-pt/termos.

Conforme exposto nos referidos Termos e Condições de Uso, o descarregamento de títulos de acesso restrito requer uma licença válida de autorização devendo o utilizador aceder ao(s) documento(s) a partir de um endereço de IP da instituição detentora da supramencionada licença.

Ao utilizador é apenas permitido o descarregamento para uso pessoal, pelo que o emprego do(s) título(s) descarregado(s) para outro fim, designadamente comercial, carece de autorização do respetivo autor ou editor da obra.

Na medida em que todas as obras da UC Digitalis se encontram protegidas pelo Código do Direito de Autor e Direitos Conexos e demais legislação aplicável, toda a cópia, parcial ou total, deste documento, nos casos em que é legalmente admitida, deverá conter ou fazer-se acompanhar por este aviso.

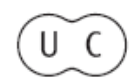




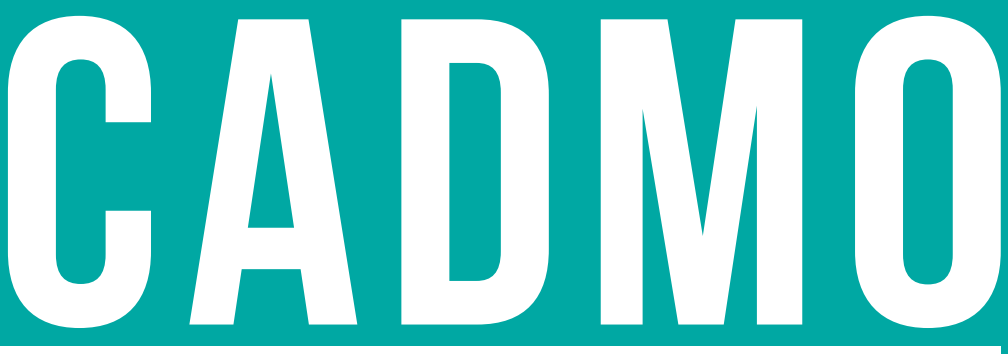

REVISTA DE HISTÓRIA ANTIGA JOURNAL FOR ANCIENT HISTORY

26

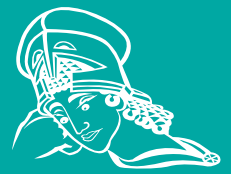

CENTRO DE HISTÓRIA DA UNIVERSIDADE DE LISBOA 2017 


\title{
EXAMINING THE DESIGN, STYLE AND LAYOUT OF THE INNER COFFIN FROM A.60 IN THE FLORENCE EGYPTIAN MUSEUM
}

Rogério Sousa Centro de Estudos Clássicos e Humanísticos (Universidade de Coimbra) Centro de História, Faculdade de Letras, Universidade de Lisboa solar.benu@gmail.com | (1) https://orcid.org/0000-0002-8253-1707

$\begin{aligned} & \text { proposta: } \\ & \text { submission }\end{aligned} \quad 02 / 04 / 2017$ | $\begin{gathered}\text { aceitação: } \\ \text { acceptance }\end{gathered} 31 / 12 / 2017$

\begin{abstract}
The burial assemblages dating from the $21^{\text {st }}$ Dynasty usually include two coffins and a mummycover. By the end of this period, coffin sets often include objects from distinct provenance, which suggests that most of them were gathered in opportunistic events. However, in some of these burials the information provided by the examination of the objects from an art historical perspective, particularly on style and scheme of decoration, reveals important clues to understand the role that coffin decoration performed during the $21^{\text {st }}$ Dynasty. In this paper we will focus on the decoration of the inner coffin from A.60 found in Bab el-Gasus so to understand the processes involved in the decoration and recycling of a coffin.
\end{abstract}

\section{Keywords}

Bab el-Gasus | Coffin decoration | Theban necropolis | 21 $1^{\text {st }}$ Dynasty 


\begin{abstract}
Resumo
Os conjuntos de ataúdes datados da XXI dinastia, são normalmente constituídos por dois ataúdes e uma cobertura de múmia. No final deste período, estes conjuntos funerários frequentemente incluem objectos de proveniência diversa, sugerindo uma combinação resultante de incidentes oportunísticos. Contudo, em alguns destes enterramentos, a informação obtida através da observação dos objectos, nomeadamente o estilo e o esquema decorativo, revela pistas importantes para compreender o papel desempenhado pelos ataúdes antropomórficos durante a XXI dinastia. Neste artigo, iremos focar-nos na decoração do ataúde interno do enterramento A.60 de Bab el-Gassus de modo a compreender alguns dos processos envolvidos na confecção e reciclagem dos ataúdes.
\end{abstract}

\title{
Palavras chave
}

Bab el-Gassus | Decoração de ataúdes | Necrópole tebana | XXI dinastia

\section{Introduction}

The burial assemblage from A.60 was found in the longitudinal gallery of Bab el-Gasus, the tomb of the priests of Amun discovered in 1891 in Deir elBahari, dating from the $21^{\text {st }}$ Dynasty. The coffin set included an outer coffin, an inner coffin and a mummy-cover. ${ }^{1}$ The quality of the objects is poor, suggesting that this burial set was given to a member of the low Theban elite. ${ }^{2}$

The scheme of decoration of the inner coffin suggests an early dating and presents a sharp contrast with the decorative scheme displayed on the outer coffin, crafted during the late $21^{\text {st }}$ Dynasty, making clear that the objects used in this burial assemblage were gathered at a later date combining objects previously used in different burials. ${ }^{3}$ In fact, the equipment of this coffin set presents abundant traces of usurpation: the outer lid shows male features and it was inscribed with the name of Ankhefekhonsu. On the other hand, the inner coffin and the mummycover show female features (earrings, lappets' binders, breasts and open hands).

\footnotetext{
Daressy 1907, 27.

2 Cooney 2014.

3 Sousa (forthcoming).
} 
The inner coffin remained anonymous but the mummy-cover was inscribed with the name of Ankhesenmut. However, Daressy found the name of Djedmut inscribed on a linen fabric put over the chest of the mummy. Another name, Henut-tani, was written on a linen tunic that wrapped the mummy. ${ }^{4}$ Given this scenario, without further documentation regarding the mummy itself, the actual identification of the deceased buried with this funerary equipment remains uncertain. ${ }^{5}$

In this rather impersonal context, the assemblage of funerary goods gathered in this coffin set seems nothing but opportunistic. However, the information provided by the examination of the objects themselves, particularly on style and scheme of decoration reveals important clues to understand when each of these objects was crafted.

In this paper we will examine the pictorial decoration of the inner coffin from A.60 from an art historical perspective so to understand the formal aspects that rule its composition and layout with a view to understand how the design involved in coffin decoration evolved during the $21^{\text {st }}$ Dynasty. ${ }^{6}$

\section{Layout}

The lid is decorated with multicolored paintwork, plaster and varnish. ${ }^{7}$ The reverse side is undecorated. The carpentry work is mediocre, with the face and the hands poorly carved. The pictorial work is slightly better, especially in terms of composition. A large floral collar displays five bands decorated with a variety of multicolored patterns bounded by falcon-headed terminals. Many anatomical features are included, such as the breasts decorated with rosettes, open hands and forearms displaying several bracelets. The arms are decorated with horizontal red lines suggesting linen stripes of a pleated garment. All these motifs are conventional from the first half of the $21^{\text {st }}$ Dynasty. ${ }^{8}$

\footnotetext{
Daressy 1907, 27.

Aston 2009, 174; Niwiński 1988, 139.

Considerations regarding the inscriptions can be consulted in Sousa, 2018 (forthcoming).

Museum inventory number: 8526 . Length: $178 \mathrm{~cm}$; Width (max): $43 \mathrm{~cm}$

8 See Sousa 2018a.
} 
The central panel, depicted over the abdomen, is clearly the most interesting composition detected on the lid. It displays two superimposed registers. In the first register a pectoral shaped as a winged scarab stands at the center of a symmetrical composition featuring an enthroned Osiris protected by a winged djed-pillar at his back and a winged cobra at his front. All these motifs are depicted over a large pet-sign symbolizing the sky.

The second register displays a beautiful depiction of a winged goddess squatted on a lotus flower outstretching her wings towards the sides of the lid. On her head she wears the monogram of Neith. Below, the lotus flower is flanked by frogs (facing outwards) springing water from their mouth to the avian manifestation of the deceased. Female $b a$-birds drink from this water with their own hands.

The lower section is decorated with a triptych panel. The central partition is decorated with vignettes displaying a sacred object at the centre of a centripetal composition: the Ta-wer-totem (first register), the sekhem-sceptre (second register), the djed-pillar (third register), the winged scarab (fourth register). The lateral partitions display four registers, each one depicting an Osirian shrine holding a deity: the enthroned Osiris (first register), the avian god Sokar resting on a sacred standard (second register), the sacred ram (third register), and two mummiform deities (fourth register). They are squatted on a beb-bowl grasping the beqa-scepter.'

The footboard of the lid follows the same tripartite organization observed on the lower section, but here the central partition is fully inscribed with four columns of text. The lateral partitions are badly damaged but traces of reversed vignettes featuring a mourning goddess squatted on a nebu-sign are detected.

The exterior decoration of the sides of the case is preserved in relatively good condition. ${ }^{10}$ The headboard shows two longitudinal cracks and the painted decoration had faded away in this area. The footboard was lost and in modern times, it was restored by adding a new wooden plank. ${ }^{11}$

Along the upper edge of the case runs a longitudinal frieze displaying alternating cobras and feathers, all facing the headboard. A block-frieze runs below.

9 On the left side the first deity is baboon-headed (Hapy) while the second is jackal-headed (Duamutef). On the right side the first god is human-headed (Imseti), while the second is falcon-headed (Kebehsenuf).

10 Museum inventory number: 8526. Length: $178 \mathrm{~cm}$; Width (max): $43 \mathrm{~cm}$; Depth: $28 \mathrm{~cm}$

11 This intervention is recorded by G. Botti in the Museum Catalogue. 
Both friezes are discontinued at the centre of the headboard. The lower edge is decorated with a thick horizontal band. The vignettes painted on the outer walls of the case are bounded by columns of hieroglyphic texts.

The headboard displays a tripartite panel. Vignette 1 (at the centre) is badly damaged but vestiges of a large tyet-sign flanked by poles of the West can be detected. Vignette 2 (left side) and Vignette 3 (right side) are symmetrical, displaying the avian manifestation of Sokar resting on a divine standard under a vaulted shrine.

On the left side, the upper section is decorated with two vignettes (Vignettes 4-5) forming a single scene depicting the god Thoth before the Ta-wer-totem. Vignette 4 depicts the ibis-headed god identified as 'Lord of Maat, while Vignette 5 shows a symmetrical composition with the Ta-wer-totem standing on the horizon flanked by winged cobras.

The lower section displays four vignettes (Vignettes 6-10). Although divided by four columns of text, the first two vignettes (Vignettes 6-7) form a single scene depicting the deceased (Vignette $\sigma$ ) before the solar bark (Vignette 7 ). The deceased wears a pleated white festive garment holding a vessel with burning incense and a libation vessel before an offering table. Vignette 7 is divided in two superimposed registers by a thick black band suggesting the pet-sign. On the upper part figures the winged scarab navigating on the solar bark, while below the head of the sacred falcon figures upside down. Rays of light irradiate from this head, shining upon a mummiform god lying on the ground. Two mummiform gods (falcon-headed on the left and baboon-headed on the right) flank the lying god. A sacred vulture (left) and a sacred cobra (right) are depicted above.

Vignette 8 displays a centripetal composition depicting three mummiform gods standing on a coiled serpent. The central ram-headed mummiform deity is flanked by a lion-headed god (left) and a jackal-headed deity (right).

Vignette 9 presents two different scenes. The first scene depicts the deceased standing before the sycamore tree, raising her arms to drink the water poured by the goddess, who stands among the leaves of the tree, clad in a tight green dress and wearing the monogram of Maat. In the juxtaposed scene the sacred cow emerges from the Theban Mountain standing on a platform depicted before the tomb depicted among the desert cliffs. Next to the foot-board, the Vignette 10 consists 
in a narrow tableau depicting the pole of the West.

The decoration of the right side recalls the scheme used on the opposite wall. The upper section is decorated with two vignettes forming a single scene depicting the god Thoth (Vignette 11) before the enthroned Osiris (Vignette 12).

Vignettes 13 and 14 form a single scene. The deceased (Vignette 13) figures before an offering stand bearing offerings (cf. Vignette 6). Vignette 14 is divided in two superimposed registers by a large pet-sign carrying the solar bark with the winged scarab. Below, figures the reversed head of the sacred falcon irradiating light upon a mummiform god lying on the ground. Two mummiform gods (falcon-headed on the left and dog-headed on the right) flank the head and feet of the lying god. A sacred vulture (left) and a sacred cobra (right) are depicted above (cf. Vignette 7 ).

Vignette 15 displays a centripetal composition depicting three mummiform gods standing on a coiled serpent (cf. Vignette 8).

Vignette 16 depicts the judgment scene, introducing the only motif unattested on the opposite side. The deceased is depicted with raised arms, with the pole of the West behind her. The heart of the deceased (left tray) is being weight on the human-headed scale against the monogram of Maat (right tray). Below the arms of the scale figure the jackal-headed god Anubis (left) and the mummiform manifestation of the deceased, squatted on the horizon. Before the scale stands the falcon-headed Horus, red-skinned and wearing the double-crown. At his feet is couched the Great Devourer (crocodile-headed?), here interestingly identified as 'Shayl, the 'Destiny'. Horus raises his right arm towards the enthroned Osiris. He is seated on the hwt-throne, wearing the bedjet-crown and the royal sceptres. The imi$w t$-totem stands at his feet, while a goddess (green skinned) clad in a tight beaded dress figures at his back, with the monogram of Isis on her head. The upper part of the scene is decorated with hieroglyphic inscriptions framed within half columns and forming captions for the whole representation. Before the falcon-headed god: 'Horus, the avenger of his father Osiris'. Before the mummiform god: 'Osiris, lord of the Duat. Before the goddess: 'Nephthys'.

Next to the foot-board, the Vignette 17 consists in a narrow tableau depicting the pole of the West. 
Inside the case, the thicknesses are stepped and painted yellow. The walls are painted red. The floorboard displays a large and imposing depiction of a goddess. She is painted with yellow skin and blue long wig. She is standing over the nebu-sign and faces left, with the arms lying along the flanks in order to embrace the mummy, once it was positioned inside the case. She wears a tall headdress composed of two feathers (yellow) and a sun disk (red). The pole of the West is depicted next to her legs, on her right side.

Although this would be the expected composition of a coffin dating from the early $21^{\text {st }}$ Dynasty, it is clear that this archaic effect was the result of a later arrangement. In fact, beneath the layer of red paint, it is possible to detect motifs and inscriptions that had been covered on a later date. Between these hidden motifs it is possible to detect the Ta-wer totem below the nub-sign where the goddess is standing. Before her face, a band of inscriptions was also covered with paint. ${ }^{12}$ Technical analysis will certainly reveal further decorative elements underneath the red paint.

\section{Style and Design}

Although apparently simple, the scheme of decoration detected in this coffin raises interesting questions considering how coffin decoration evolved during the $21^{\text {st }}$ Dynasty in Thebes.

The style detected on the case is naturalistic and harmonious, featuring anatomical details with accuracy and beauty. The compositions are outlined in a sketchy way but the result is surprisingly good, suggesting the hand of a skilled and talented artist. The background of the iconographic tableaux hardly features liminal elements (also called 'space-fillers') ${ }^{13}$ which also points to an early dating of the object. ${ }^{14}$

On the lid the style is schematic and roughly executed, lacking the gracious expressivity detected on the case. Although it would be tempting to see these

12 For the usual scheme of the interior decoration see Taylor 2016, 60. See also Liptay 2011, Pl. 3.

13 These elements are only to be detected in Vignette 7 and 14.

14 Sousa 2018a, 108-109. 
differences as resulting from different 'hands', given the collective nature of Egyptian craftsmanship it is more likely that they resulted either from the work of different workshops or from a different dating. The beautiful style observed on the case suggests an earlier craftsmanship, while on the lid one can already foresee the schematic trend which would prevail in coffin decoration during the second half of the dynasty. ${ }^{15}$ As Kathlyn Cooney pointed out, ${ }^{16}$ it is likely that the lid and case belonged to two separate coffins and that they were brought together on a later date.

The design of the two objects also reveal important differences regarding the weight played by innovations. The decoration of the case reveals key-features which date the object from the first half of the $21^{\text {st }}$ Dynasty. The decoration of the sides displays a rather conventional scheme, provided with a highly narrative structure. As we approach the footboard (which is here clearly associated with the West) ${ }^{17}$ the integration of the deceased in the Duat is unfolded before our eyes. Preceded by Thot, the deceased witnesses the solar-Osirian mysteries ${ }^{18}$ and undergoes herself the trial of the dead in the court of Osiris before new life and rebirth is granted to her by the mother goddess herself. The major difference detected on the sides is focused on the last vignette before the foot-board, which introduces the idea of a blessed afterlife, either in the form of a successful outcome in the judgement of the dead (right side - Vignette 16) or in the nourishment by the tree/mother goddess (Vignette 9). ${ }^{19}$ The iconographic programme of the sides is thus coherent and highly conservative regarding the Theban tradition of coffin decoration. ${ }^{20}$

The decoration of the footboard and upper section of the lid remained fairly conventional displaying all the key-features expected to be observed in coffin decoration during the first half of the $21^{\text {st }}$ Dynasty. The depiction of the forearms dates the lid from the first half of the $21^{\text {st }}$ Dynasty, but some features can be dated from the mid- $21^{\text {st }}$ Dynasty, such as the triptych panel featured on the lower section. ${ }^{21}$

15 Sousa 2018a, 175.

16 Cooney (forthcoming).

17 Vignettes 10 and 17 simply depict the totem of the West.

18 Osiris is depicted as an enthroned god on the right side (Vignette 12) and he is alluded to as the Ta-uer totem on the left side (Vignette 5).

19 A variation on this scheme can be found in the case of Ankhesenmut. See Dodson 2015, 20.

20 For a similar programme see the anonymous coffin from Bab el-Gasus (25016.2.2, Vatican Museums), in Gasse 1996, Pl. XXV.

21 Sousa 2018a, 173. 
In this respect, the central panel is perhaps one of the most telling compositions, revealing a transitional structure evolving from the typical scheme used during the first half of the $21^{\text {st }}$ Dynasty, which included two registers (basic scheme) ${ }^{22}$ to the three registers observed from the mid-21 ${ }^{\text {st }}$ Dynasty onwards (classical scheme). ${ }^{23} \mathrm{In}$ this particular composition we see two main registers and a secondary one displayed below the wings of the goddess. As it is typical in these transitional compositions, this smaller register is highly innovative. Unlike the main registers, which reveal a highly standardized structure, the lower register displays a rather unexpected composition involving $b a$-birds drinking water spat out by frogs. The freshness of this register reveals the experimental nature of the processes involved in coffin decoration. ${ }^{24}$

This innovative result stands out when considering the highly conservative layout detected in the remaining decoration of the lid. This sharp contrast clearly shows that the deliberate search for new results in coffin decoration was selectively carried out in each section at a time. A similar situation is detected in a small sample of objects, probably assigned to the same workshop, where we witness to identical experimentations. ${ }^{25}$ Clearly, the painters involved in the decoration of these objects were very well acquainted with the norms and principles of coffin decoration and in fact they observe them exhaustively. Each section displays the main key-features that are exactly to be expected. The careful observance of the normative layout makes the innovative arrangement of the central panel even more meaningful, suggesting that when exploring the possibilities offered by a new layout, painters deliberately used innovative solutions. In any case, the layout of this composition clearly dates the pictorial work carried out in this coffin lid next to the mid-21 ${ }^{\text {st }}$ Dynasty.

It is clear that innovative results were not achieved randomly but by using an experimental design that observed most of the established conventions and introduced subtle variations focused on certain key-elements. This experimental approach to generate variability and innovative results could only take place under learned supervision.

22 See, for example, the inner lid of Ankhefenmut (ÄS 6267a) in Egner et Haslauer 1992, Pl. 8.

23 See, for example, the inner lid of Tabaketkhonsu (ÄS 6265) in Egner et Haslauer 1992, Pl. 18.

24 Sousa 2014.

25 Coffin of A.18 (Musées royaux d'Art et d'Histoire). See Sousa 2018b, fig. 4. See also Delvaux et Therasse 2016. Mummy-cover of A.29 (British Museum, EA 24790) in Sousa 2018b, fig. 5. 
The differences detected on the lid and the case suggest that innovation played an increasing bolder role as we approach the mid- $21^{\text {st }}$ Dynasty. However, this same object provides yet more evidence regarding another trend that would reveal to be equally important during this period.

As we have seen, the interior of the case was repainted at a later date aiming to erase the secondary motifs that surrounded the main goddess. ${ }^{26}$ This operation clearly suggests that the object having been crafted during the first half of the $21^{\text {st }}$ Dynasty was later selectively repainted in order to look older. This evidence is particularly intriguing as most of the better documented situations of reuse show that later interventions aimed at updating the scheme of decoration of older objects. ${ }^{27}$ Normally, a coffin would be recycled by introducing the newest achievements. However, this particular object was recycled with the opposite purpose aiming at suggesting that it would actually look older than it was. In fact, it is known that during the late $21^{\text {st }}$ Dynasty, the key-features used in the first stages of coffin decoration were revived, particularly in the burials of the highest elite, originating an archaising trend. ${ }^{28}$

As we have already stated elsewhere, ${ }^{29}$ the concept of 'archaization' is problematic as sometimes different phenomena are gathered under this same label. Archaization is sometimes associated with the reuse and recycling, but in fact it is a different phenomenon. When recycling an object, some of the original features might be kept, either because they were praised enough to be maintained or just because it was not possible to erase them. However, this cannot be confused with the process of producing an object using a scheme of decoration of old, aiming at making it 'look older' than it actually was.

While the recycling of an object shows how the decorative program was reinterpreted on a later dating, archaization deals with the craftsmanship of an object following an 'old-fashioned' scheme of decoration.

The operation carried out in the floorboard of the inner coffin from A.60 clearly shows that the object was recycled at a much later date, possibly shortly

26 For an example of the expected programme on the floor-board see Gasse 1996, Pl. XXVI.

27 Cooney 2014.

28 Sousa 2014.

29 Sousa 2018a, 176. 
before the reuse of these objects in the assemblage of A.60. At this moment, certainly mindful of the antiquity of the case, craftsman decided to enhance its vintage look by eradicating most of the secondary motifs.

\section{Conclusion}

It is certain that behind a heterogeneous group of objects such as we have in the coffin set of A.60 we usually find nothing more than an opportunistic assemblage. However, in this particular burial, it seems that a choice was made so to form a representative group, gathering objects regarded as relatively new, such as the outer coffin, and vintage items praised as "antiques", such as the inner lid and case. Moreover, the inner coffin clearly shows that during the late $21^{\text {st }}$ Dynasty the taste for vintage objects increased and, as a result of that, Theban workshops tried to make old coffins look even older. Such retrograde taste might actually explain the occurrence of outdated or old-fashioned coffins in the burials dating from the late $21^{\text {st }}$ Dynasty.

This retrograde taste for 'antiques' has to be explained at the light of the development of coffin decoration itself. In fact, from the Ramesside period onwards, coffin decoration became a cutting edge industry having evolved towards unprecedented levels of complexity. During this process of development, some objects introduced important innovations while others simply followed the established conventions. In the last stages of this process, in the late $21^{\text {st }}$ Dynasty, learned individuals could thus distinguish from the extraordinary wealth of funerary goods available in the Theban storerooms "ordinary" objects from "unique" pieces that could catch the eye of a "collector". It is therefore possible that, after the extreme development that took place in coffin decoration during the $21^{\text {st }}$ Dynasty, a retrograde revival of the older stages of coffin decoration have occurred, thus inspiring what can be called as an "archaic" trend. In this context, it is possible that some objects achieved an especial value as "antiques".

The inner coffin from A.60 alone reveals two different strategies used in the late $21^{\text {st }}$ Dynasty to form an assemblage that could be perceived at this later stage as 'old'. The obvious process was to look for vintage objects available for 
re-use. Another process consisted in recycling old coffins to make them look even older. Both processes required learned supervision both to acknowledge a rare and antique object and to "recreate" one. These processes became important enough to generate an archaizing trend during the late $21^{\text {st }}$ Dynasty.

When we look at the objects belonging to the coffin set A.60, we may therefore witness the choice of a connoisseur on Theban funerary art. This phenomenon can also be detected in other burial assemblages from Bab el-Gasus, such as in A.136, where a similar assemblage of traditional and newly crafted objects took place. ${ }^{30}$ Archaization, understood as an appreciation of the first stages of coffin decoration, thus seems to have played an important role in the late $21^{\text {st }}$ Dynasty and on itself it evolved as a reaction to the unprecedented levels of complexity achieved in coffin decoration during this period. The use of the models of old thus seems to have gained a social significance on itself. The ongoing study on the style and decoration of the coffins found in Bab el-Gasus will certainly contribute to understand how these processes shaped coffin decoration in the Theban necropolis. 


\section{BIBLIOGRAPHY}

Aston, David. 2009. Burial assemblages of Dynasty 21 - 25: chronology - typology - developments. Wien: Verl. der Österr. Akad. der Wiss (Contributions to the chronology of the Eastern Mediterranean 21).

Cooney, Kathlyn. 2014. "Ancient Egyptian Funerary Arts as Social Documents: Social Place, Re-use, and Working Towards a New Typology of 21st Dynasty Coffins.” In Body, Cosmos, and Eternity: New Research Trends in the Iconography and Symbolism of Ancient Egyptian Coffins, ed. Rogério Sousa, 45-66. Oxford: Archaeopress (Archaeopress Egyptology 3).

- Forthcoming. "Coffin re-use in the $21^{\text {st }}$ Dynasty: A case study of the Bab el-Gasus coffins in the Florence Egyptian Museum.” In The Lot V of Bab el-Gasus at the Florence Egyptian Museum, ed. Rogério Sousa.

Daressy, George. 1907. "Les cercueils des prêtres d'Ammon (deuxième trouvaille de Deir el-Bahari." In Annales du Service des Antiquités de l'Égypte (8):3-38.

Delvaux, Luc et Therasse, Isabelle. 2016. Sarcophages. Sous les Étoiles de Nout. Bruxelles: Racine.

Dodson, Aidan. 2015. Ancient Egyptian Coffins: The Medelhavsmuseet Collection. Stockholm: Världskulturmuseerna.

Gasse, Annie. 1996. Les sarcophages de la Troisième Période Intermédiaire du Museo Gregoriano Egizio. Cittá del Vaticano: Vatican Museums.

Egner, Roswitha et Haslauer, Elfried. 1992. Kunsthistorisches Museum Wien, Ägyptisch-Orientalische Sammlung, Lieferung 8: Uschebti 2. Mainz/Rhein: Philipp von Zabern (Lose-Blatt-Katalog ägyptischer Altertümer).

Liptay, Éva. 2011. Coffins and coffin fragments of the Third Intermediate Period. Budapest: Museum of Fine Arts.

Niwiński, Andrzej. 1988. 21st Dynasty coffins from Thebes: chronological and typological studies. Mainz: Zabern.

Sousa, Rogério. 2014. "Spread your wings over me: Iconography, Symbolism and Meaning of the Central Panel on yellow coffinsv." In Body, Cosmos \& Eternity: New research trends in the symbolism of coffins in ancient Egypt, edt. Rogério Sousa, 91-109. Oxford: Archaeopress (Archaeopress Egyptology 3, 45-66).

- 2017. Burial assemblages from Bab el-Gasus in the Geographical Society of Lisbon. Brepols: Bruxelles (Monumenta Aegyptiaca, vol. 17)

2018a. Gleaming coffins: Iconography and symbolism in Theban coffin decoration (21 ${ }^{\text {st }}$ Dynasty). Coimbra: Coimbra University Press (forthcoming).

. 2018b. "The genealogy of images: Innovation and complexity in coffin decoration during dynasty 21". In Ancient Egyptian coffins: craft, traditions and functionality, edt. John Taylor. London: British Museum (forthcoming).

- Forthcoming. The Lot $V$ of Bab el-Gasus at the Florence Egyptian Museum.

Taylor, John. 2016. "Coffins from the New Kingdom to the Roman Period." In Death on the Nile: Uncovering the Afterlife of Ancient Egypt, eds. Julie Dawson, Helen Strudwick, 49-75. Cambridge: The Fitzwilliam Museum.

Van Walsem, René. 1997. The coffin of Djedmonthuiufankh in the National Museum of Antiquities at Leiden. Leiden: (Egyptologische Uitgaven 10). 


\section{List of Figures}

Fig. 1: Inner lid (A.60). Courtesy of the Florence Egyptian Museum

Fig. 2: Inner lid (A.60) - Central panel. Courtesy of the Florence Egyptian Museum

Fig. 3: Inner case (A.60) - Right side. Courtesy of the Florence Egyptian Museum

Fig. 4: Inner case (A.60) - Left side. Courtesy of the Florence Egyptian Museum

Fig. 5: Inner case (A.60) - Interior decoration. Courtesy of the Florence Egyptian Museum 


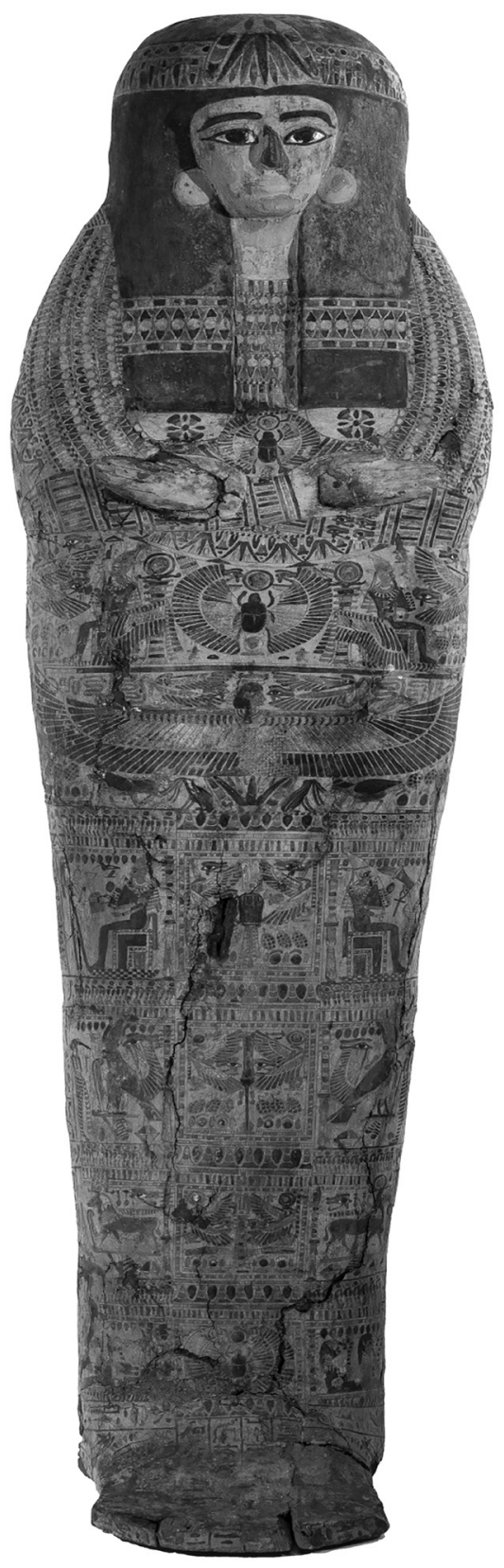

Fig. 1: Inner lid (A.60) 



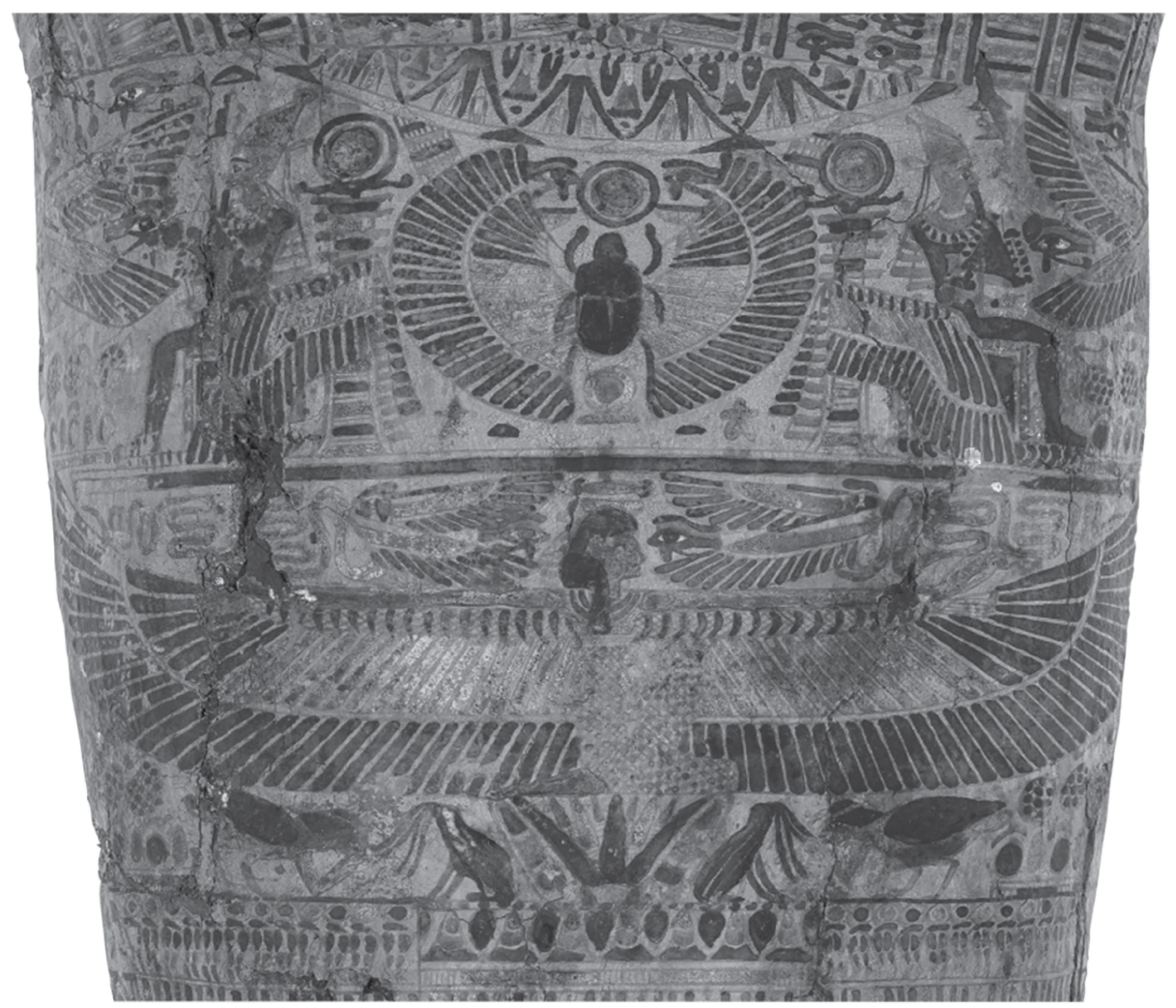

Fig. 2: Inner lid (A.60) 



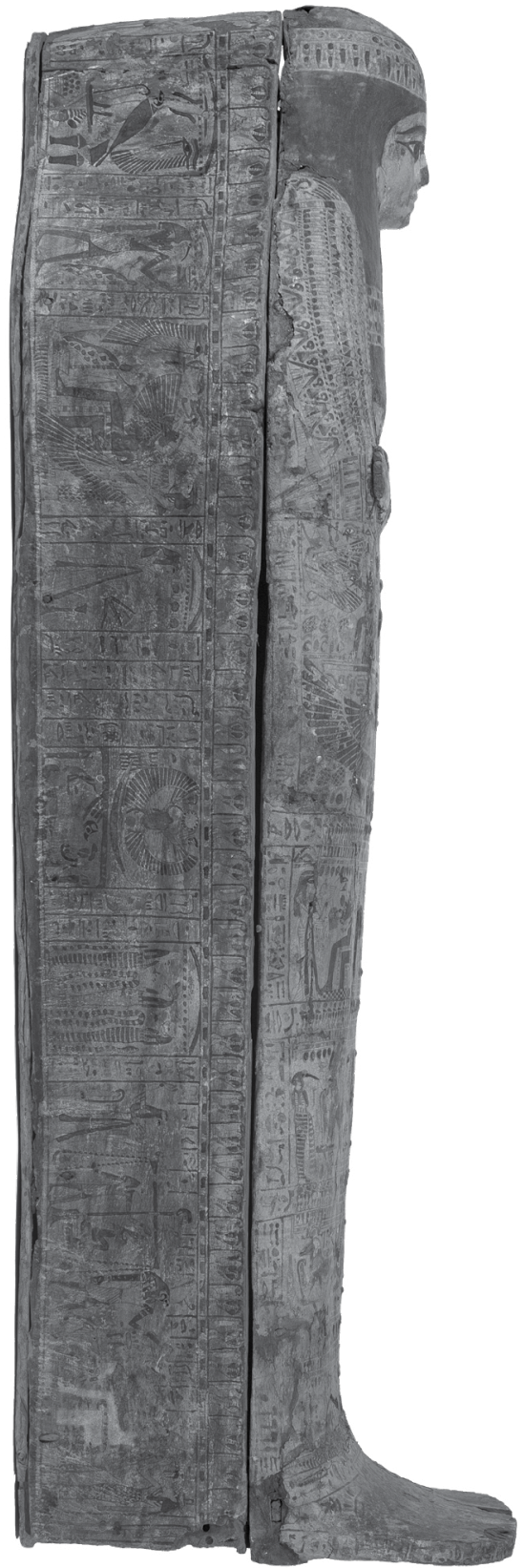

Fig. 3: Inner lid (A.60) - Right side 



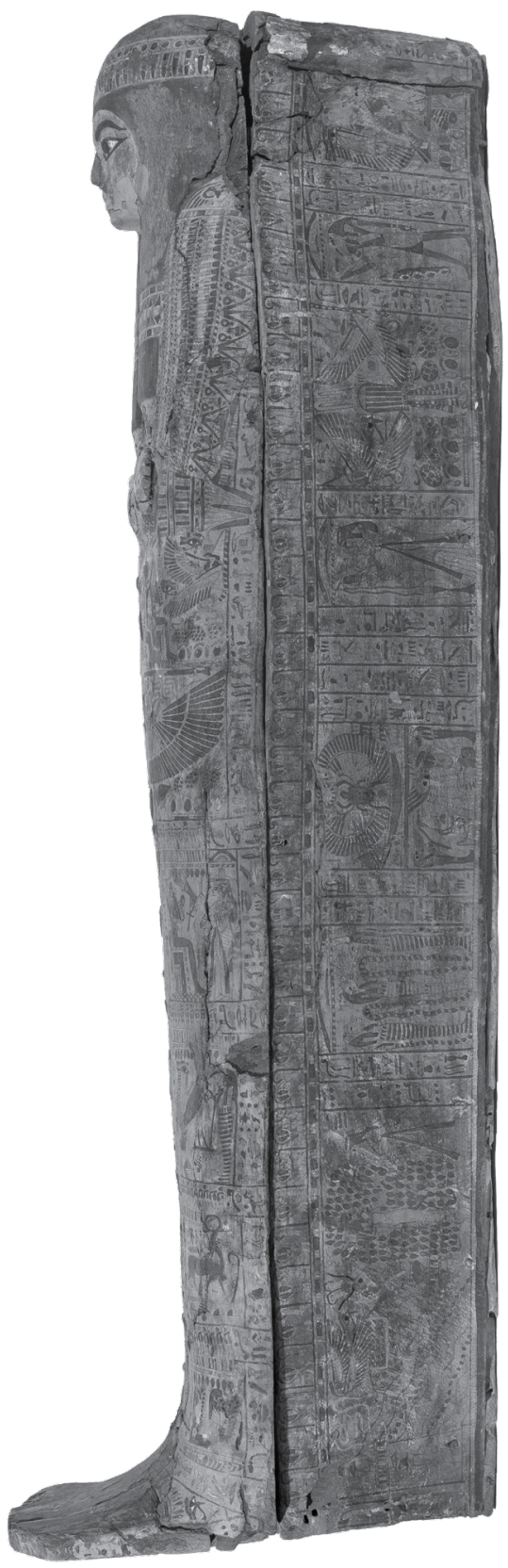

Fig. 4: Inner lid (A.60) - Left side 



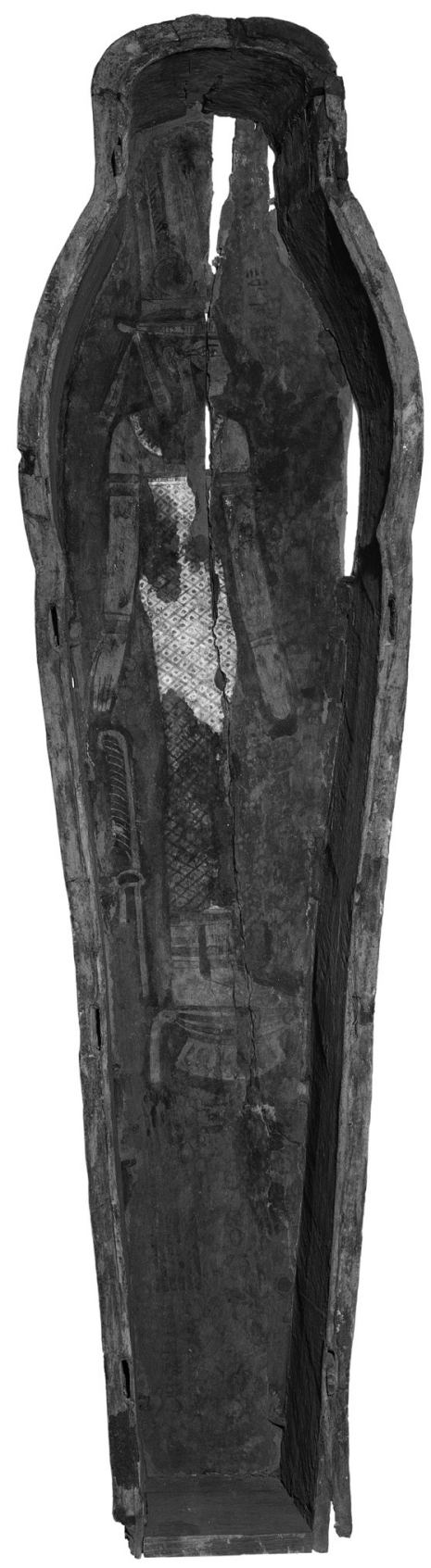

Fig. 5: Inner lid (A.60) - Interior decoration 